\title{
Comparison of satellite imagery from LISS-III/Resourcesat-1 and TM/ Landsat 5 to estimate stand-level timber volume
}

\author{
Elias Fernando Berra1* ${ }^{1 *}$ Denise Cybis Fontana1, Tatiana Mora Kuplich² \\ 1 Universidade Federal do Rio Grande do Sul, Av. Bento Gonçalves, 9500, CEP 91501-970, Porto Alegre, RS, Brazil \\ ${ }^{2}$ Instituto Nacional de Pesquisas Espaciais, Campus Universitário C P 5021, CEP 97105-970, Santa Maria, RS, Brazil
}

"Autor correspondente:

eliasberra@yahoo.com.br

Index terms:

Pinus elliottii

Reflectance

Forest inventory

Termos para indexação:

Pinus elliotti

Reflectância

Inventário florestal

Histórico do artigo:

Recebido em 23/01/2016

Aprovado em 16/12/2016

Publicado em 30/12/2016

doi: 10.4336/2016.pfb.36.88.1134

\begin{abstract}
After Landsat 5 activities were discontinued, sensors on board ResourceSat-1 satellite have been pointed as an option for Landsat series. The aim of this study is to estimate timber volume from a slash pine (Pinus elliottii Engelm.) stand using images from both LISS-III/ResourceSat-1 and TM/Landsat 5 sensors, cross comparing their performances. Reflectance values from the four spectral bands considered equivalent for both sensors were compared regarding sensitivity to changes in timber volume. Trends were similar, with direct relationship in the near-infrared bands and inverse relationships in the visible and mid-infrared bands. Significant differences were only found in the equivalent band of green. Multiple linear regressions were used to select spectral bands that would better explain variations in timber volume. The best fit equations for each sensor were inverted to generate maps of timber volume, estimates which were compared at pixel and stand level. None of the scales showed significant differences between estimates generated from the two sensors. We concluded that LISS-III and TM have generally very similar performance for monitoring timber volume, and LISS-III could therefore be potentially used as a complement or substitute to Landsat series.
\end{abstract}

\section{Comparação das imagens de satélite LISS-III/Resourcesat-1 e TM/ Landsat 5 para estimar volume de madeira de talhões florestais}

Resumo - Após a interrupção das atividades do Landsat 5, sensores a bordo do satélite ResourceSat-1 têm sido apontados como uma opção à série Landsat. O objetivo deste estudo é estimar volume de madeira de pinus (Pinus elliottii Engelm.) por meio de imagens dos sensores LISS-III/ResourceSat-1 e TM/Landsat 5, comparando suas performances. Valores de reflectância das quatro bandas espectrais equivalentes em ambos os sensores foram comparados quanto à sensibilidade a mudanças no volume de madeira. As tendências foram similares com relações diretas nas bandas do infravermelho próximo e relações inversas nas bandas do visível e infravermelho médio. Diferenças significativas foram encontradas somente nas bandas equivalentes do verde. Regressões lineares múltiplas foram aplicadas para selecionar as bandas espectrais que melhor explicariam as variações em volume de madeira. As equações com melhores ajustes para cada sensor foram invertidas para gerar mapas de volume de madeira, cujas estimativas foram comparadas à escala de pixel e de talhão. Nenhuma das escalas mostrou diferenças significativas entre as estimativas geradas pelos dois sensores. Concluiu-se que os sensores LISS-III e TM apresentam, em geral, desempenho muito similar para monitoramento de volume de madeira, e que o LISS-III poderia, consequentemente, ser usado em complemento ou em substituição à série Landsat. 


\section{Introduction}

Forest-based supply chain is dependent upon plantations capable of producing high quality trees at the end of rotation. This requires frequent monitoring of the forest conditions, which is traditionally made with aid of forest biophysical parameters sampled during forest inventories. Parameters such as timber volume, basal area and height are required for effective and successive resource management (Zimble et al., 2003; Chubey et al., 2006; Gunlu et al., 2014) being essential in all levels of forest management planning (Baskent et al., 2005). However, due to high costs, traditional forest sampling (although highly accurate) generally comprises less than $3 \%$ of the total area (Trotter et al., 1997) often from priority stands. Some information for those areas not inventoried can potentially be obtained by medium and high spatial resolution satellite images (Ardo, 1992; Trotter et al., 1997; McDonald et al., 1998; Gunlu et al., 2014). Satellite images have been used as an essential component in the development of new tools for forest management (Chiavetta et al., 2008; Zakaria, 2010), bringing new opportunities to monitor forests with reasonable costs and time (Gunlu et al., 2014).

Imagery from Landsat series have been used historically for estimating biophysical parameters of vegetation (Boyd \& Danson, 2005; Williams et al., 2006). However, users have been experiencing some constraints if Landsat images over the years 2011-2013 are required, as Landsat 5 was retired in 2011 (Nasa, 2014) and the ETM+ sensor aboard Landsat 7 has technical challenges to be addressed due to the scan line corrector off (Markham et al., 2004; Xiaolin \& Desheng, 2014). Despite Landsat 8 became fully operational in 2013 (Nasa, 2014), difficulties in using Landsat images over 2011-2013 period have highlighted the importance to investigate other potential substitutes (Chen et al., 2013).

There is a need and demand for satellite observations from moderate spatial resolution sensors (10-100 m), such as the ones aboard Landsat (Goward et al., 2009, 2011), as they are adequate for global studies and detailed enough to monitor human scale processes (Xiaolin \& Desheng, 2014). IRS series (Indian Remote Sensing Satellites) have been pointed out as an alternative option
(Chander \& Stensaas, 2008; Wulder et al., 2008; Gill et al., 2012), for comparable observations of Earth's surface (Goward et al., 2012; Berra et al., 2014).

LISS-III sensor (Linear Imaging Self Scanner-III), aboard ResourceSat-1 IRS satellite, has been pointed out as the sensor that provided the best combination with TM/Landsat 5 in terms of spectral bands and data accessibility (Chander \& Stensaas, 2008; Teillet \& Ren, 2008; Berra et al., 2014).

Although ResourceSat and Landsat sensors ' radiometric performances have been compared (Chander \& Stensaas, 2008; Anderson et al., 2011; Gill et al., 2012) there is no study, to our knowledge, comparing the performance of LISS-III with TM for estimating forest biophysical parameters. This motivates research on their potential application within the forestry field, investigations which could allow one same phenomenon or feature to be observed at different scales.

The aim of this study is to estimate timber volume from a slash pine stand by using images from both LISS-III/ResourceSat-1 and TM/Landsat 5 sensors, cross comparing their performances. Spectral reflectance values from the four spectral bands considered equivalent to both sensors were compared regarding their sensitivity to change in timber volume.

\section{Methods}

\section{Study area and fieldwork}

The study was conducted within stands of slash pine (Pinus elliottii Engelm.) distributed in 12,000 ha covering c. $15 \mathrm{~km}$ of coastline located in the most south state of Brazil (Figure 1. Slash pine plantation in Rio Grande do Sul State, Brazil, imaged by the sensors TM/ Landsat 5 (path-row 221/83) and LISS-III/ResourceSat 1 (path-row 328/103).). The climate of the region, according to Koppen-Geiger classification system, is humid subtropical (Cfa). The region has an average air temperature of $23.1^{\circ} \mathrm{C}$ in summer and $13.4^{\circ} \mathrm{C}$ in winter and average annual rainfall of 1,155.6 $\mathrm{mm}$ (Centro Estadual de Meteorologia, 2011). The relief is rather plain (Sistema..., 1999), rising only a few meters above the sea level (Weber et al., 2004). The Quartzipsamment soil type is characteristic of the area (Sistema..., 1999). 


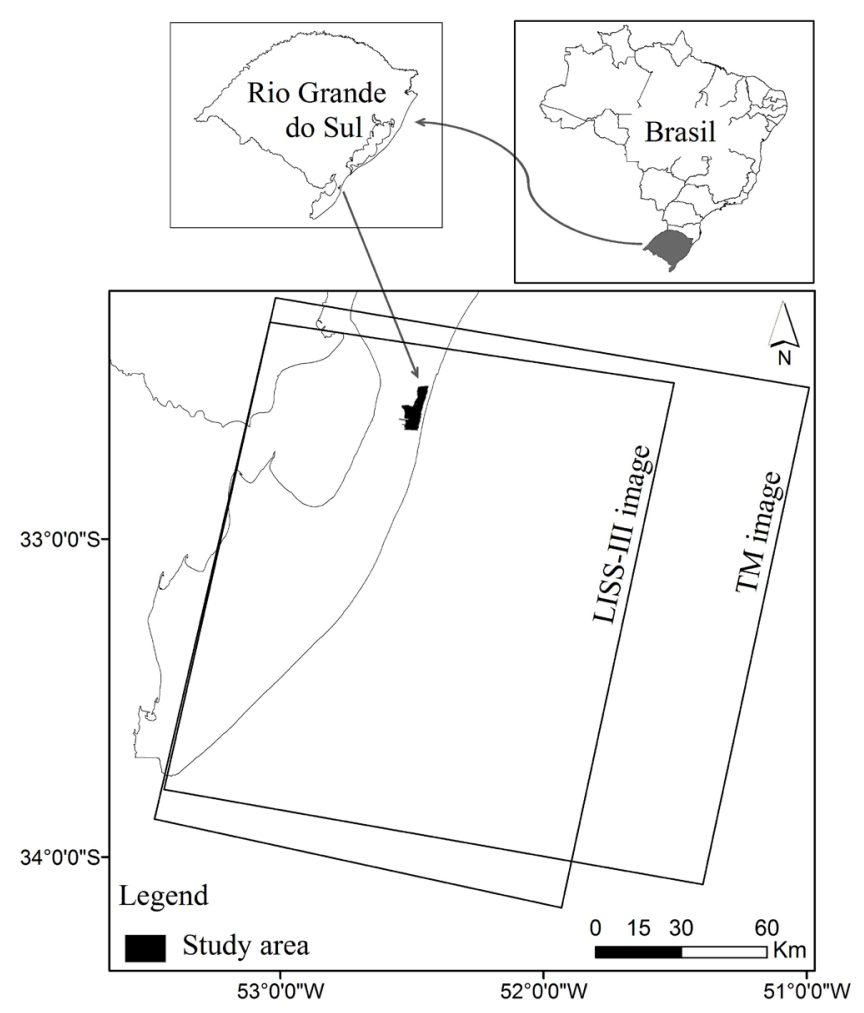

Figure 1. Slash pine plantation in Rio Grande do Sul State, Brazil, imaged by the sensors TM/Landsat 5 (path-row 221/83) and LISS-III/ResourceSat 1 (path-row 328/103).

A forest inventory was conducted over selected stands, data which were used to validate the satellitederived information. The survey was carried out during September and October 2010 in young slash pine stands aged between 5 and 8 years old. The inventory systematically allocated one sampling unit (SU) at every 6 ha, totalizing 111 SUs. Each SU had a fixed area of $420 \mathrm{~m}^{2}$, with sides proportional to a $2 \times 3 \mathrm{~m}$ planting spacing, which in turn resulted in c. 70 trees measured per SU. For every tree within a SU, diameter at breast height (dbh) and total tree height (h) were measured; Dbh and $h$ were then used to estimate timber volume (V) in $\mathrm{m}^{3} \cdot \mathrm{ha}^{-1}$ (Equation 1) within each SU. As form factors were not known, a general value of 0.5 was assumed in Equation (1). The calculated timber volume values ranged from 3.2 to $200.3 \mathrm{~m}^{3}$.ha-1.

$$
\mathrm{V}=\frac{10,000}{420} \times \sum_{i=1}^{n} \pi \times \frac{d b h_{i}^{2}}{4} \times h_{i} \times 0.5
$$

$\mathrm{V}=$ timber volume $\left(\mathrm{m}^{3} \cdot \mathrm{ha}^{-1}\right), \mathrm{dbh}=$ diameter at breast height (m), h = total tree height $(\mathrm{m}), \mathrm{n}=$ number of trees measured.

The geographical coordinates of each SU (centre) were collected by a Garmin's eTtrex Legend ${ }^{\circledR}$ GPS.

\section{Satellite images}

Table 1 Main characteristics of sensors TM and LISS-III aboard satellites Landsat 5 and ResourceSat-1, respectively. summarizes the main characteristics of TM and LISS-III sensors. Their relative spectral responses can be seen in Chander \& Stensaas (2008). Only the spectral bands considered equivalents to both sensors were selected in our study: green (B2), red (B3), nearinfrared (NIR) (B4) and mid-infrared (MIR) (B5).

Table 1. Main characteristics of sensors TM and LISS-III aboard satellites Landsat 5 and ResourceSat-1, respectively.

\begin{tabular}{|c|c|c|}
\hline \multirow{2}{*}{ Band } & TM & LISS-III \\
\hline & \multicolumn{2}{|c|}{ Spectral resolution $(\mu \mathrm{m})$} \\
\hline 2 & $0.52-0.60$ & $0.52-0.59$ \\
\hline 3 & $0.63-0.69$ & $0.62-0.68$ \\
\hline 4 & $0.76-0.90$ & $0.77-0.86$ \\
\hline \multirow[t]{9}{*}{5} & $1.55-1.75$ & $1.55-1.70$ \\
\hline & \multicolumn{2}{|c|}{ Spatial resolution (m) } \\
\hline & 30 & 23.5 \\
\hline & \multicolumn{2}{|c|}{ Radiometric resolution (bits) } \\
\hline & 8 & 7 \\
\hline & \multicolumn{2}{|c|}{ Temporal resolution (days) } \\
\hline & 16 & 24 \\
\hline & \multicolumn{2}{|c|}{ Swath width $(\mathrm{km})$} \\
\hline & 185 & 141 \\
\hline
\end{tabular}

Source: (Chander et al., 2009; Nasa, 2014).

$\mathrm{TM} /$ Landsat 5 (path-row 221/83 of September $7^{\text {th }}$, 2010) and LISS-III/ResourceSat-1 images (path-row $328 / 103$ of September $26^{\text {th }}, 2010$ ) were selected for this study (Figure 1), as these dates coincided with the forest inventory. The original images' pixel values were firstly converted to absolute units of at-sensor spectral radiance (Chander et al., 2009) and thereafter to surface reflectance using the module FLAASH (Fast Line-ofsight Atmospheric Analysis of Spectral Hypercubes) available with ENVI software.

Reflectance images were georeferenced based on 12 ground control points collected with a GARMIN eTrex Legend $\AA$ GPS (planimetric errors $<6 \mathrm{~m}$ ), which yielded a RMSE (Root Mean Square Error) of less than 0.5 pixel. Bilinear resampling technique was chosen to warp the data, as a SU area could be intersected by more than one pixel. Pixels which intersected the SU's central coordinate were selected and their reflectance were extracted.

Pesq. flor. bras., Colombo, v. 36, n. 88, p. 363-373, out./dez. 2016 


\section{Data analysis and estimation of timber volume}

The relationships between spectral reflectance and timber volume were first analysed with aid of scatter plots, fitted by regression curves. Equivalent bands were submitted to z-test (Montgomery et al., 2006) in order to test for significant differences $(Z>|1.96|)$, at a confidence level of $95 \%$.

Regression analysis was used to determine the spectral bands (independent variables) that best estimate timber volume (dependent variable). Selection of the best equation, for each sensor, was based on adjusted coefficient of determination $\left(\mathrm{R}_{\text {adj. }}^{2}\right)$, standard error of estimate $\left(\mathrm{S}_{\mathbf{y x}}\right)$, calculated $\mathrm{F}$ value, bias and residuals distribution (Orue, 2002; Watzlawick et al., 2009; Berra et al., 2012).

Selected equations were thereafter used to generate timber volume maps over 22 compartments of slash pine. In addition to these maps, timber volumes estimated by LISS-III and TM were compared at pixel and stand level with aid of scatter plots. The relative difference was also analysed ((LISS-III - TM)/TM). At pixel level, the 111 pixels intersecting the corresponding 111 SUs were selected. At stand level, mean value of timber volume within each compartment was calculated. Finally, differences in mean timber volume estimated by the two sensors were tested by ANOVA (Analysis of variance), with $95 \%$ confidence interval.

\section{Results}

Scatter plots between timber volume and spectral reflectance from TM and LISS-III imagery pointed out similar trends (Figure 2). Direct and linear relationships were observed with NIR bands and curvilinear and inverse relationships with the other bands. TM data set presented linear correlation coefficient (r) values smaller than those obtained with LISS-III. However, differences were only statistically significant with the green band (B2) $(Z=2.31)$.

All the equations tested to estimate timber volume were significant at a confidence interval greater than
99\% (Table 2). Multiple linear equations returned the best fits (N. 5/LISS-III and N. 10/TM, Table 2), as they presented higher $\mathrm{R}_{\text {adj. }}^{2}$, smaller $\mathrm{S}_{\mathrm{yx}}$, smaller bias and residuals distribution less biased. $\mathrm{R}^{2}$ adj. values obtained with LISS-III were higher than those obtained with TM, except for the equation that used B4. However, differences were only statistically significant between equations that used the equivalent green bands (B2).

The bias values suggest underestimation of timber volumes (Table 2). However, the analysis of residuals within the range of timber volumes inventoried (3.7 to $200.3 \mathrm{~m}^{3} \cdot \mathrm{ha}^{-1}$ ) showed an overestimation around smaller volumes $\left(<50 \mathrm{~m}^{3} \cdot \mathrm{ha}^{-1}\right)$ and as volumes increase the trend is reversed. Residual plots (not presented here) showed, in general, larger bias occurring in volumes above 100 $\mathrm{m}^{3}$.ha ${ }^{-1}$, which correspond to trees that are 7-8 years old, ages which coincide with the starting of total closure of canopies.

Maps of slash pine timber volume were generated by using the best fitted equations (N. 5 and N. 10, Table 2). By visual interpretation, TM-based estimates have generated a higher timber volume than the LISSIII-based ones. This trend is also confirmed by the quantitative information extracted from the maps (Figure $3)$.

The comparison of timber volume estimated by LISS-III and TM images at pixel level shows data pairs are generally distributed around 1:1 line, but with a dominance of points above this line (66\% of the total) (Figure 4a). The relative differences (Figure 4c) best illustrates this fact, where the predominance of negative values indicates that LISS-III estimated smaller timber volumes than TM (12\% less, on average). However, these differences were found to be not statistically. Comparisons at stand level (22 stands) showed that $82 \%$ of the points (18 points) were above the 1:1 line (Figure 4b). This in turn resulted in a predominance of negative values in the relative difference plot (Figure 4d), as LISS-III estimated smaller timber volumes than TM (11\% less, on average). The differences were not statistically different. 

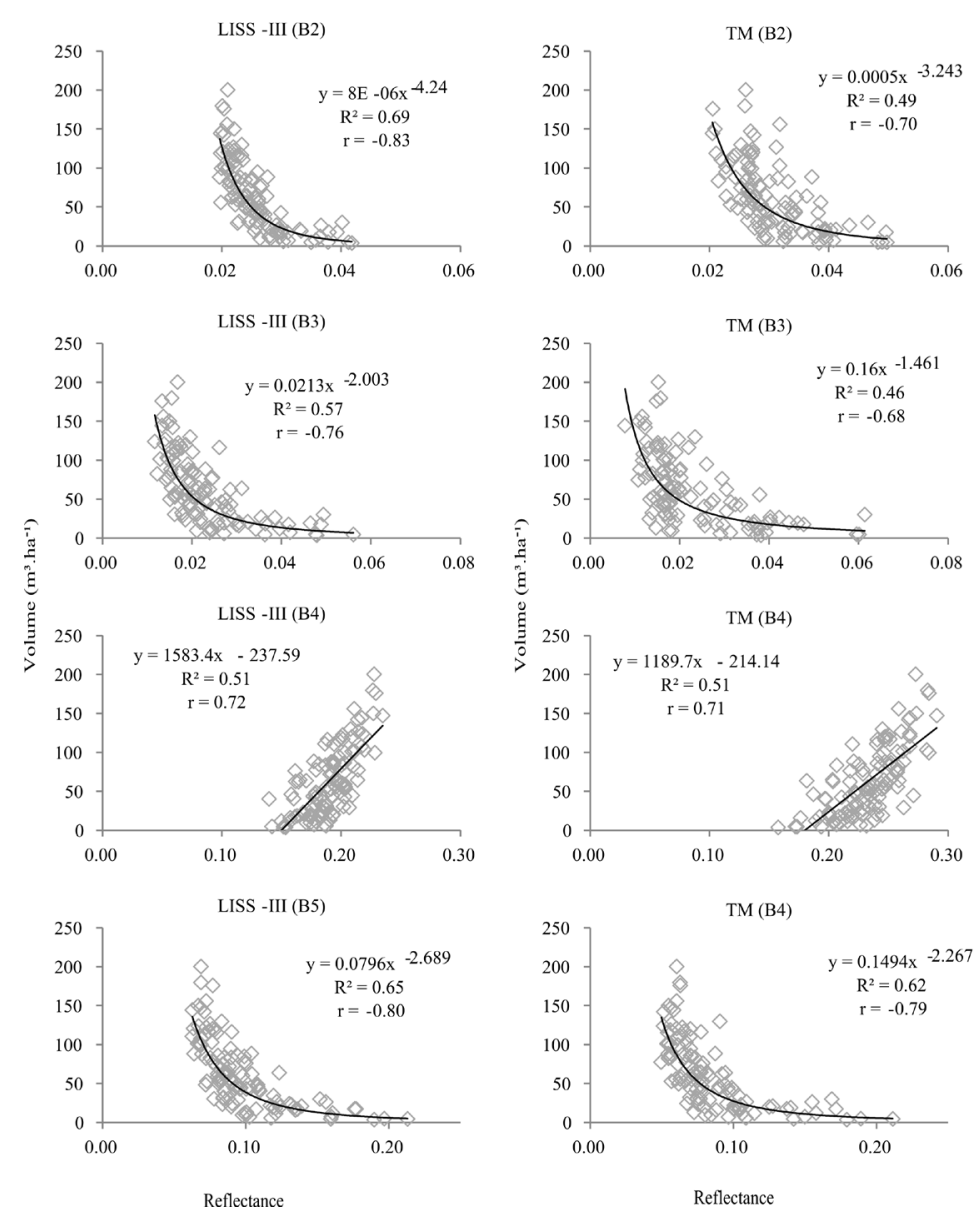

Figure 2. Dispersion between slash pine's timber volume and green (B2), red (B3), near-infrared (B4) and mid-infrared (B5) bands from LISS-III and TM imagery.

Table 2. Equations tested to estimate slash pine's timber volume using surface spectral reflectance from LISS-III and TM sensors' images as independent variables.

\begin{tabular}{|c|c|c|c|c|c|c|}
\hline Sensor & N. & Regression equation $^{1}$ & $\mathbf{F}$ & $\mathbf{R}_{\text {adj. }}^{2}$ & $\begin{array}{c}\mathbf{S}_{\mathrm{yx}} \\
\left(\mathbf{m}^{3} \cdot \mathbf{h a}^{-1}\right)\end{array}$ & $\begin{array}{c}\text { Bias } \\
\left(\mathbf{m}^{3} \cdot \mathbf{h a}^{-1}\right) \\
\end{array}$ \\
\hline \multirow{5}{*}{ LISS-III } & 1 & $-11.74-4.24 \times \operatorname{Ln}(\mathrm{B} 2)$ & $242.43 * *$ & 0.69 & 27.11 & 5.65 \\
\hline & 2 & $-03.85-2.00 \times \operatorname{Ln}(\mathrm{B} 3)$ & $147.17 * *$ & 0.57 & 32.08 & 7.44 \\
\hline & 3 & $13.51+5.82 \times \operatorname{Ln}(\mathrm{B} 4)$ & $098.20 * *$ & 0.47 & 30.34 & 8.71 \\
\hline & 4 & $-02.53-2.69 \times \operatorname{Ln}(\mathrm{B} 5)$ & $197.85^{* *}$ & 0.65 & 28.87 & 6.57 \\
\hline & 5 & $-5.1-3.4 \times \operatorname{Ln}(\mathrm{B} 2)+2.1 \times \operatorname{Ln}(\mathrm{B} 4)$ & $142.98 * *$ & 0.72 & 24.60 & 4.32 \\
\hline \multirow{5}{*}{$\mathrm{TM}$} & 6 & $-07.54-3.24 \times \operatorname{Ln}(\mathrm{B} 2)$ & $107.18 * *$ & 0.49 & 35.41 & 8.38 \\
\hline & 7 & $-01.83-1.46 \times \operatorname{Ln}(\mathrm{B} 3)$ & $094.15 * *$ & 0.46 & 36.34 & 9.19 \\
\hline & 8 & $11.97+5.57 \times \operatorname{Ln}(B 4)$ & $114.89 * *$ & 0.51 & 31.15 & 8.22 \\
\hline & 9 & $-01.90-2.27 \times \operatorname{Ln}(\mathrm{B} 5)$ & $180.02 * *$ & 0.62 & 31.69 & 7.12 \\
\hline & 10 & $1.32-1.2 \times \operatorname{Ln}(\mathrm{B} 2)+2.8 \times \operatorname{Ln}(\mathrm{B} 4)-\operatorname{Ln}(\mathrm{B} 5)$ & $087.95^{* *}$ & 0.70 & 25.24 & 5.63 \\
\hline
\end{tabular}

Note: ${ }^{1}$ Equations estimate the natural logarithm of timber volume; $\mathrm{N} .=$ number of regression equation; $* *$ Significant at $0.000, \mathrm{~F}=$ calculated value; $\mathrm{R}_{\text {adj. }}^{2}=$ adjusted coefficient of determination; $\mathrm{Syx}=$ standard error of the estimate; $\mathrm{Bias}=$ mean of residual biases; $\mathrm{B} 2=$ green spectral band; $\mathrm{B} 3 \stackrel{\text { adj. }}{=}$ red spectral band; $\mathrm{B} 4=$ near-infrared spectral band; $\mathrm{B} 5=$ mid-infrared spectral band. 


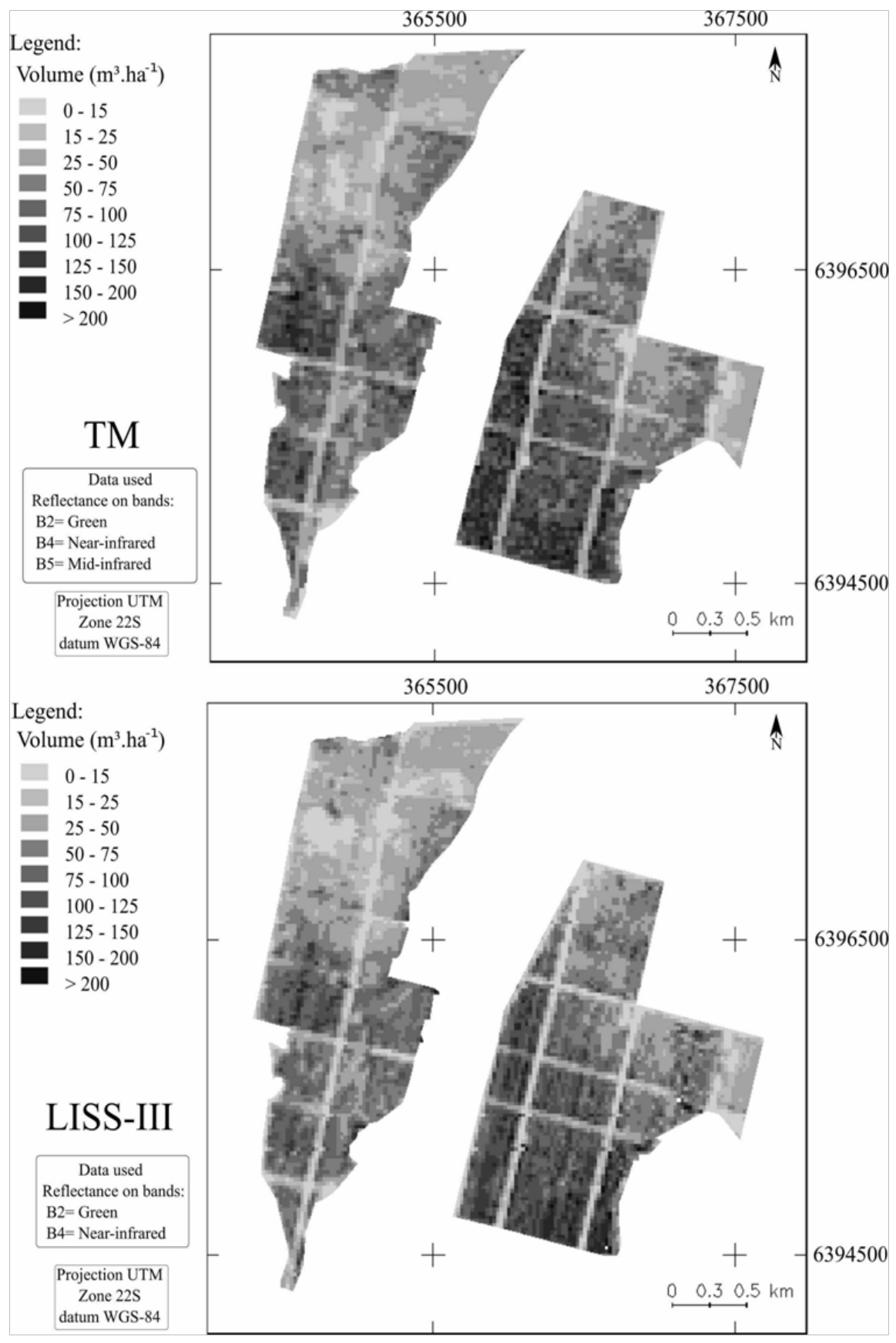

Figure 3. Timber volume maps of slash pine stands estimated by spectral reflectance from LISS-III and TM imagery. 

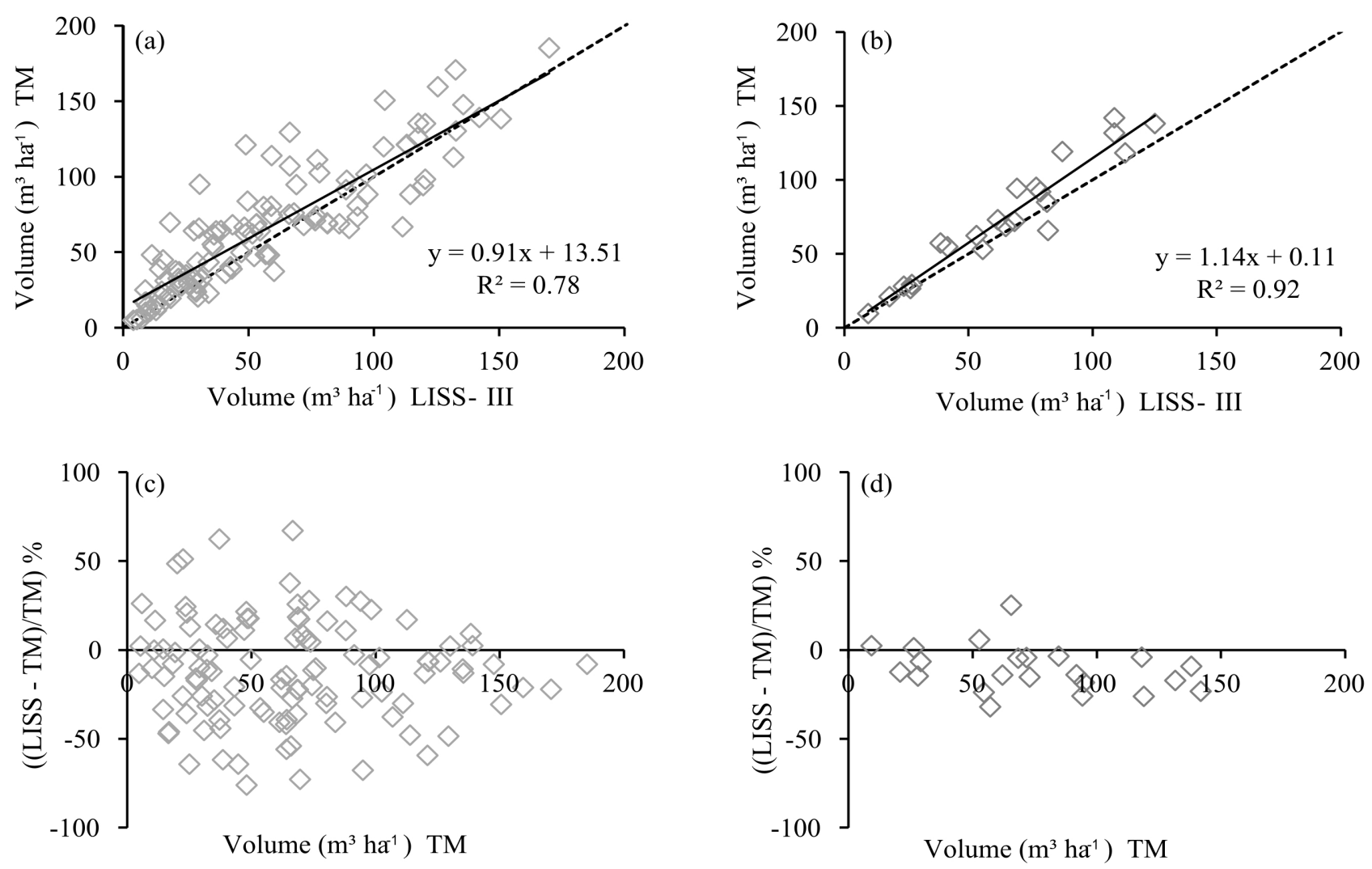

Figure 4. Comparison of slash pine's timber volume estimated by LISS-III and TM images: a) at pixel level, b) at stand level, c) relative difference at pixel level, and d) relative difference at stand level. The dashed lines (a-b) represent a 1:1 line.

\section{Discussion}

Tree stems growth in height and diameter results in increased timber volume. This in turn increases the amount of green leaves in the canopy (this is valid for young stands) and modifies the signal intensity detected by the sensors LISS-III and TM (Figure 2). In the visible bands (B2 and B3), the increasing in timber volume caused a reduction in reflectance, which might be attributed to the increased absorption of visible radiation by leaf pigments (Gates, 1970; Myers et al., 1970; Woolley, 1971), resulting in negative slopes; a similar trend is observed with the mid-infrared band (B5), but increased absorption can be attributed to the presence of water in the living tissues (Gates, 1970; Woolley, 1971). On the other hand, NIR reflectance (B4) increased with increasing timber volumes, what can be explained by a strong scattering and weak absorptance by canopy leaves over this spectral region (Gausman et al., 1969; Woolley, 1971), occasioning a positive slope. Figure 2 shows that LISS-III and TM spectral bands detected changes of timber volume in a similar way.

Previous studies that examined associations between field and optical satellite imagery data over forest areas found inverse relationships between forest biophysical parameters and visible and MIR spectral bands (Franklin, 1986; Ripple et al., 1991; Ardo, 1992; Berra et al., 2012), while varied relationships were found when using NIR band (Franklin, 1986; Spanner et al., 1990; Puhr \& Donoghue, 2000). The direct relationship found between NIR and timber volume in this study can be attributed to two key factors characterizing the slash pine plantation: age and type of management. Studies which reported an inverse relationship between NIR 
band and forest biophysical parameters attributed this fact due mainly to the presence of understory and/or shading (Ripple et al., 1991; Trotter et al., 1997; Puhr \& Donoghue, 2000). Spanner et al. (1990) found a strong positive linear relationship between LAI (leaf area index) and NIR radiance only in stands which had little or no contribution from understory.

The forest stands under study were managed to not allow growth of understory vegetation, practice which resulted in a background class totally covered by litterfall. Therefore, when analysing the spectral response within this stand, and bearing in mind the concept of pixel mixture (Shimabukuro \& Smith, 1991), it would be expected that: 1) the spectral reflectance of the vegetation portion within a pixel should be only due to the overstory (slash pine's canopy); 2) the spectral reflectance of the soil portion should be due to the litterfall layer, since it completely covers the sandy soil, 3) Shadow effects, which reduce radiance measured by a sensor (Franklin, 1986; Spanner et al., 1990), should be minimal since young plantations do not present fully canopy closure (for most SUs); in addition, trees (same age and species within a compartment) presented relative homogeneous heights, i.e., all canopies were in the same stratum, therefore preventing one canopy to shade each other with great intensity (as usually occurs with native forests and older commercial plantations). Besides that, the area is rather flat, which eliminates shadowing due to terrain slope.

Therefore, the absence of understory, relative little shading, a constant layer of litterfall and open canopy in most SUs acted together to increase NIR reflectance values with increasing timber volumes (Figure 2). When vegetation canopy is not totally closed, the spectral signal is composed by the brightness of either soil or understory, modified by the amount of vegetation covering it (Franklin, 1986). The wide spectral radiance of stands with small timber volumes $\left(<150 \mathrm{~m}^{3} \cdot \mathrm{ha}^{-1}\right)$ can be partially explained by the smaller amount of shade, which will result in a greater contribution to the spectral radiance coming from the soil and from vegetation cover (Ardo, 1992).

Spectral reflectance values tended to saturate from c. $150 \mathrm{~m}^{3} \cdot \mathrm{ha}^{-1}$ over the slash pine area, as detected by both LISS-III and TM imagery (Figure 2). Values around and above $150 \mathrm{~m}^{3}$.ha- ${ }^{-1}$ come from stands with 7 to 8 years, ages which coincided with the beginning of the complete canopy closure. From this point onwards, the influence of the background class (litterfall) in the canopy`s spectral response becomes minimal, which is expected to difficult the modelling of forest biophysical parameters by optical satellite imagery. Once the canopy closes, timber volume is associated with the reflectance of the canopy only through changes in LAI (Franklin, 1986; Danson \& Curran, 1993). Puhr \& Donoghue (2000) stated that it is very difficult to predict biophysical forest parameters from Landsat TM imagery after canopy closes, as the reflected radiance of a forest is strong dependent of its background class. Their conclusion could be therefore extended to LISS-III data, as this sensor proved to be similar to TM (Chander \& Stensaas, 2008; Anderson et al., 2011; Gill et al., 2012)

Although the two sensors are in general similar regarding sensitivity to changes in timber volume, a detailed analysis reveals differences in the so-called equivalent bands (Figure 2), what was already expected as there might be several sources of variability. Differences between two imaging sensors might be caused by a combination of terrestrial target's spectral signature, atmospheric composition and the features of the relative spectral response curve (RSR) of each sensor (Chander et al., 2009). It could be also added issues related to the different spatial resolutions and difficulties to accurately register the TM and LISS-III images.

Therefore, a combination of factors works together to influence the reflected radiance detected and stored by an orbital sensor, what may limit the precision of studies aiming at modelling the relationships between biophysical variables and spectral data. In this study, the spectral data accounted for up to $72 \%$ of the timber volume variability with LISS-III (Equation N. 5 in Table 2) and up to $70 \%$ with TM (Equation N. 10 in Table 2). $\mathrm{R}_{\text {adj }}^{2}$ values ranged from 0.47 to 0.72 with LISS-III and, similarly, from 0.47 to 0.70 with TM. This range of values over commercial forests agrees with other studies.

Xavier (1998) estimated LAI of Eucalyptus sp. plantations based on data from TM/Landsat 5 and found an equation with $\mathrm{R}^{2}$ of 0.69 . A study by Puhr \& Donoghue (2000) concluded that height and basal area of coniferous plantations were more closely associated with bands 3 , 5 and 7 of TM/Landsat $5\left(\mathrm{R}^{2}>0.77\right)$, while the weakest relationships were found with band $4\left(\mathrm{R}^{2}<0.23\right)$; Orue (2002) estimated timber volume of Pinus spp. with ETM+/Landsat 7 and found $\mathrm{R}^{2}$ of 0.43 ; Canavesi et al. (2010) estimated timber volume of Eucalyptus spp. using EO-1 Hyperion data and found $\mathrm{R}^{2}$ values ranging 
from 0.62 to 0.70 ; Berra et al. (2012) found $\mathrm{R}_{\text {adj }}^{2}$ values between 0.61 and 0.68 in equations predicting timber volume of Eucalyptus sp., whose independent variables came from TM/Landsat 5 imagery.

Regarding transferability of empirical relationships between spectral data and forest parameters, several authors emphasize limitations for such purpose because of the dependence of site and sensor scene (McDonald et al., 1998; Foody et al., 2003; Berra et al., 2012). Therefore, one sensor cannot simply replace another for observation of the same phenomenon, despite their similarity, without prior analysis of how they are related to each other.

In this study, the similarities of the sensors LISS-III and TM were investigated in terms of their spectral reflectances and their potential to estimate timber volume. By comparing the volume maps (Figure 3) it can be seen that classes mapped with aid of TM data do not always correspond to the same classes as mapped with aid of LISS-III in the same area. However, there were no large discrepancies. For example, when LISS-III associated an area with a class $15-25 \mathrm{~m}^{3} \cdot \mathrm{ha}^{-1}$, TM associated the same area with this same class or with an adjacent class rather than a distant one (e.g., 150-200 $\mathrm{m}^{3}$.ha $\mathrm{h}^{-1}$ ), which, in turn, resulted in maps not identical but quite similar.

This tendency of similar results between the two sensors is better quantified in Figure 4. Despite similar trends, the fits are not unbiased and that is most evident at pixel level, where differences were up to around $50 \%$. As discussed previously, there are several factors contributing for the final spectral response detected by each sensor, which will ultimately result in different products (in this case, timber volume estimates). Figure 4 also shows that stand-level estimates presented higher $\mathrm{R}^{2}$ values than pixel-level ones, what can be attributed to a smoothing out of variability caused by averaging pixel values within a compartment boundary.

In summary, the results achieved point out to a possibility of integration between LISS-III and TM images. In this sense, natural resource assessments that have historically been done with TM data, may find in the LISS-III images an alternative replacement to Landsat series, mainly in the period 2011-2013. Even with Landsat 8 providing high quality images and assuring the Landsat series continuity (Nasa, 2014), LISS-III/ ResourceSat-1 can play a crucial role as a complement or substitute sensor to Landsat 8. This is because such satellites have different revisit periods and consequently observe the same area on days that are mostly different. Therefore, ResourceSat-1 could be an option for cloudy images from Landsat 8, for example.

\section{Conclusions}

The spectral reflectance values from the four spectral bands considered equivalent for sensors LISS-III and TM have, generally, a similar sensitivity to changes in timber volume. Both sensors have also very similar performance for estimating timber volume of commercial forests.

These findings suggest that LISS-III imagery could potentially be used as a complement and ultimately as a substitute to TM data, at least for estimates of forest biophysical parameters. However, one should be fully aware that significant differences may exist, mainly in a per-pixel basis.

Finally, the fact that traditional forest inventory sampling usually covers less than $3 \%$ of the planted area and given the synoptic character of satellite images, the use of the methodology here presented may be encouraged to aid in forest inventory of commercial stands.

\section{Acknowledgment}

The first author would like to thank the Conselho Nacional de Desenvolvimento Científico e Tecnológico (CNPq) (grant 134017/2011-0) for funding this work as part of his Master's. We would also like to thank TREFLOR for allow us to use the forest inventory data.

\section{References}

Anderson, J. H. et al. Intercalibration and Evaluation of ResourceSat-1 and Landsat-5 NDVI. Canadian Journal of Remote Sensing, v. 37, n. 2, p. 213-219, 2011. DOI: 10.5589/m11-032.

Ardo, J. Volume quantification of coniferous forest compartments using spectral radiance recorded by Landsat Thematic Mapper. International Journal of Remote Sensing, v. 13, n. 9, p. 1779-1786, 1992. DOI: $10.1080 / 01431169208904227$.

Baskent, E. Z. et al. The forest management planning system of Turkey: constructive criticism towards the sustainable management of forest ecosystems. International Forestry Review, v. 7, n. 3, p. 208-217, 2005. 
Berra, E. F. et al. Comparação da reflectância espectral e do IVDN dos sensores LISS-III/RESOURCESAT-1 e TM/LANDSAT $5 \mathrm{em}$ povoamento florestal. Revista Brasileira de Cartografia, v. 1, n. 66/2, p. 393-406, 2014.

Berra, E. F. et al. Estimativa do volume total de madeira em espécies de eucalipto a partir de imagens de satélite Landsat. Ciência Florestal, v. 22, n. 4, p. 853-864, 2012. DOI: 10.5902/198050987566.

Boyd, D. S. \& Danson, F. M. Satellite remote sensing of forest resources: three decades of research development. Progress in Physical Geography, v. 29, n. 1, p. 1-26, 2005. DOI: 10.1191/0309133305pp432ra.

Canavesi, V. et al. Estimativa de volume de madeira em plantios de Eucalyptus spp. utilizando dados hiperespectrais e dados topográficos. Revista Árvore, v. 34, n. 3, p. 539-549, 2010. DOI: 10.1590/s0100-67622010000300018.

Centro Estadual de Meteorologia (Rio Grande do Sul). Atlas climático do Rio Grande do Sul. Porto Alegre, 2011. Available at: $<$ http://www.cemet.rs.gov.br/area/7/Atlas_Clim\%C3\%A1tico $>$. Acess onar.ch 5, 2012.

Chander, G. \& Stensaas, G. L. Evaluation of Candidate Landsat Data Gap Sensors. In: IEEE INTERNATIONAL GEOSCIENCE AND REMOTE SENSING SYMPOSIUM, 2008 : IGARSS 2008. Boston, Massachusetts. Proceedings... Piscataway: IEEE, 2008. p. IV1376-IV 1379.

Chander, G. et al. Summary of current radiometric calibration coefficients for Landsat MSS, TM, ETM+, and EO-1 ALI sensors. Remote Sensing of Environment, v. 113, n. 5, p. 893-903, 2009. DOI: 10.1016/j.rse.2009.01.007.

Chen, X. et al. Cross-sensor comparisons between Landsat 5 TM and IRS-P6 AWiFS and disturbance detection using integrated Landsat and AWiFS time-series images. International Journal of Remote Sensing, v. 34, n. 7, p. 2432-2453, 2013. DOI: 10.1080/01431161.2012.743690.

Chiavetta, U. et al. Estimation of forest attributes by integration of inventory and remotely sensed data in Alto Molise. Rivista Italiana Di Telerilevamento, v. 40, n. 1, p. 89-106, 2008. DOI: 10.5721/ ItJRS20084018.

Chubey, M. S. et al. Object-based analysis of Ikonos-2 imagery for extraction of forest inventory parameters. Photogrammetric Engineering and Remote Sensing, v. 72, n. 4, p. 383-394, 2006.

Danson, F. M. \& Curran, P. J. Factors affecting the remotely sensed response of coniferous forest plantations. Remote Sensing of Environment, v. 43, n. 1, p. 55-65, 1993. DOI: 10.1016/0034-425, 1999. 412p.

Foody, G. M. et al. Predictive relations of tropical forest biomass from Landsat TM data and their transferability between regions. Remote Sensing of Environment, v. 85, n. 4, p. 463-474, 2003. DOI: 10.1016/S0034-4257(03)00039-7.

Franklin, J. Thematic mapper analysis of coniferous forest structure and composition. International Journal of Remote Sensing, v. 7, n. 10, p. 1287-1301, 1986. DOI: 10.1080/01431168608948931.
Gates, D. M. Physical and physiological properties of plants. In: REMOTE sensing with special reference to agriculture and forestry: with special reference to agriculture and forestry. Washington, DC: National Academy of Sciences, 1970. p.164-223.

Gausman, H. W. et al. Reflectance of cotton leaves and their structure. Remote Sensing of Environment, v. 1, n. 1, p. 19-22, 1969. DOI: 10.1016/S0034-4257(69)90055-8.

Gill, T. K. et al. Comparing bright-target surface spectral-reflectance estimates obtained from IRS P6 LISS III to those obtained from Landsat 5 TM and Landsat 7 ETM+. Remote Sensing Letters, v. 3, n. 2, p. 121-130, 2012. DOI: 10.1080/01431161.2010.543180.

Goward, S. N. et al. Complementarity of ResourceSat-1 AWiFS and Landsat TM/ETM+ sensors. Remote Sensing of Environment, v. 123, p. 41-56, 2012. DOI: 10.1016/j.rse.2012.03.002.

Goward, S. N. et al. Moderate spatial resolution optical sensors. In: Warner, T. A. et al. (Ed.). The SAGE handbook of remote sensing. London: SAGE Publications, 2009. p. 123-138.

Goward, S. et al. The Future of Landsat-Class Remote Sensing. In: Ramachandran, B. et al. (Ed.). Land remote sensing and global environmental change. New York: Springer, 2011. p.807-834. (Remote sensing and digital image processing, 11).

Gunlu, A. et al. Prediction of some stand parameters using pansharpened IKONOS satellite image. European Journal of Remote Sensing, v. 47, p. 329-342, 2014. DOI: 10.5721/EuJRS20144720.

Markham, B. L. et al. Landsat-7 ETM+ on-orbit reflective-band radiometric stability and absolute calibration. Geoscience and Remote Sensing, IEEE Transactions on, v. 42, n. 12, p. 2810-2820, 2004. DOI: 10.1109/TGRS.2004.836389.

McDonald, A. J. et al. Investigation of the utility of spectral vegetation indices for determining information on coniferous forests. Remote Sensing of Environment, v. 66, n. 3, p. 250-272, 1998. DOI: 10.1016/s0034-4257(98)00057-1.

Montgomery, D. C. et al. Introduction to linear regression analysis. 4th ed. New York: Hoboken, N.J. : Wiley-Interscience, c2006, 2006. 612 ISBN 0470542810.

Myers, V. I. et al. Soil, water, and plant relations. In: REMOTE sensing with special reference to agriculture and forestry. Washington, DC: National Academy of Sciences, 1970. p.164-223.

Nasa. Landsat science. 2014. Available at: < http://landsat.gsfc.nasa. gov/ >. Acess on: April 21, 2014.

Orue, N. E. Estimativa de volume de povoamentos de Pinus spp. utilizando dados do satélite Landsat 7. 2002. Dissertação (Mestrado em Ciências Florestais) - Universidade Federal do Paraná, Curitiba.

Puhr, C. B. \& Donoghue, D. N. M. Remote sensing of upland conifer plantations using Landsat TM data: a case study from Galloway, south-west Scotland. International Journal of Remote Sensing, v. 21, n. 4, p. 633-646, 2000. DOI: 10.1080/014311600210470.

Ripple, W. J. et al. A preliminary comparison of landsat thematic mapper and SPOT-1 HRV multispectral data for estimating coniferous forest volume. International Journal of Remote Sensing, v. 12, n. 9, p. 1971-1977, 1991. 
Shimabukuro, Y. E. \& Smith, A. The least-squares mixing models to generate fraction images derived from remote sensing multispectral data. Geoscience and Remote Sensing, IEEE Transactions on, v. 29, n. 1, p. 16-20, 1991. DOI: 10.1109/36.103288.

SISTEMA Brasileiro de Classificação de Solos. Brasília, DF: Embrapa Produção de Informação; Rio de Janeiro: Embrapa Solos, 1999. 412 p.

Spanner, M. A. et al. Remote sensing of temperate coniferous forest leaf area index The influence of canopy closure, understory vegetation and background reflectance. International Journal of Remote Sensing, v. 11, n. 1, p. 95-111, 1990. DOI: 10.1080/01431169008955002.

Teillet, P. M. \& Ren, X. Spectral band difference effects on vegetation indices derived from multiple satellite sensor data. Canadian Journal of Remote Sensing, v. 34, n. 3, p. 159-173, 2008.

Trotter, C. M. et al. Estimation of timber volume in a coniferous plantation forest using Landsat TM. International Journal of Remote Sensing, v. 18, n. 10, p. 2209-2223, 1997. DOI: 10.1080/014311697217846.

Watzlawick, L. F. et al. Estimativa de biomassa e carbono em floresta com araucaria utilizando imagens do satélite Ikonos II. Ciência Florestal, v. 19, n. 2, p. 169-181, 2009. DOI: 10.5902/19805098408.

Weber, E. et al. Adaptação do modelo digital de elevação do SRTM para o sistema de referência oficial brasileiro e recorte por unidade da federação. Porto Alegre: UFRGS Centro de Ecologia, 2004. Available at: <http://www.ecologia.ufrgs.br/labgeo/>. Acess on: 10 Mar. 2013.
Williams, D. L. et al. Landsat: yesterday, today, and tomorrow. Photogrammetric Engineering and Remote Sensing, v. 72, n. 10, p. 1171-1178, 2006. DOI: 10.14358/PERS.72.10.1171.

Woolley, J. T. Reflectance and transmittance of light by leaves. Plant physiology, v. 47, n. 5, p. 656-662, 1971. DOI: 10.1104/pp.47.5.656.

Wulder, M. A. et al. Landsat continuity: Issues and opportunities for land cover monitoring. Remote Sensing of Environment, v. 112, n. 3, p. 955-969, 2008. DOI: 10.1016/j.rse.2007.07.004.

Xavier, A. C. Estimativa de propriedades biofísicas de plantações de eucaliptos a partir de dados Landsat-TM. 1998. $116 \mathrm{f}$. Dissertação (Mestrado em Sensoriamento Remoto) - Instituto Nacional de Pesquisas Espaciais, São José dos Campos.

Xiaolin, Z. \& Desheng, L. MAP-MRF Approach to Landsat ETM+ SLC-Off Image Classification. Geoscience and Remote Sensing, IEEE Transactions on, v. 52, n. 2, p. 1131-1141, 2014. DOI: 10.1109/TGRS.2013.2247612.

Zakaria, H. E. A. Integration of Remote Sensing and GIS in Studying Vegetation Trends and Conditions in the Gum Arabic Belt in North Kordofan, Sudan. 2010. 146 f. (Doctor of Natural Science) - Institute of Photogrammetry and Remote Sensing, Technical University of Dresden, Dresden, Germany.

Zimble, D. A. et al. Characterizing vertical forest structure using small-footprint airborne LiDAR. Remote Sensing of Environment, v. 87, n. 2-3, p. 171-182, 2003. DOI: 10.1016/s0034-4257(03)001391. 
